\title{
Úspěšné prosazení empirického sociálního výzkumu v poválečném Norsku
}

\author{
HYNEK JEŘ ÁBEK*
}

\author{
The Successful Introduction of Empirical Social Research in Post-War Norway
}

\begin{abstract}
The aim of the study is to examine the actors and circumstances that led to the establishment of the Columbia model of empirical social research in Norway between 1947 and 1955. The article analyses Lazarsfeld's first European sabbatical in Oslo and looks for the links between his activities, the objectives of other actors, and the development of sociology at University of Oslo. The active level of interest among young academics and students at this university in the model of sociology practised at Columbia University in New York helped to initiate the whole process. Support from Rockefeller Foundation, Fulbright Programme, Norwegian industrialists, and the rector of the university also paved the way for the successful implementation of the model. The article concludes by describing the formation of the Institute for Social Research in Oslo and the strengthening of its position in the Norwegian academic system in the early 1950s. It is also worth remembering the importance of Paul Lazarsfeld, who, though he was not always on the scene, evidently contributed to the ultimately successful process of the institutionalisation of empirical sociology in Norway.
\end{abstract}

Keywords: Empirical Social Research; Columbia School of Sociology; University of Oslo; Institute for Social Research; Paul Lazarsfeld; Rockefeller Foundation; Fulbright Exchange Programme

DOI: $10.14712 / 23363525.2021 .5$

\section{Úvod}

V minulém článku v Historické sociologii [Jeřábek 2019] jsem odpovídal na otázku, jak a čím přispěli svými vědeckými publikacemi členové Kolumbijské sociologické školy Paul F. Lazarsfeld, Robert K. Merton a další k proměně sociologie v teoreticko-empirickou vědní disciplínu. Všestranná vědecká, učitelská a organizační aktivita Paula Lazarsfelda na Kolumbijské univerzitě a v The Bureau of Applied Social Research (dále BASR) je všeobecně známa a stala se předmětem několika reprezentativních publikací, např́ílad v podání Allena Bartona [1982], Paula Neuratha [1979], Davida Silse [1987] a dalších. James Coleman dokonce na Lazarsfeldovu adresu poznamenal: „Paul Lazarsfeld byl jedním z těch vzácných sociologů, kdo formoval směr oboru pro následující generace "[Coleman 1982: 1]. Podle Jamese Colemana i podle Davida Silse [Sills 1987: 276] to byl především tento badatel, kdo významně přispěl $k$ výše zmiňované změně podoby sociologie ze spekulativní teoretické disciplíny v empiricky založenou standardní vědu. V kolumbijském modelu sociologie má tak vedle týmové vědecké práce své místo empirický výzkum a pokročilá metodologie analýzy dat. Zároveň tento prístup staví na teoretickém zakotvení výzkumu

\footnotetext{
Prof. PhDr. Hynek Jeřábek, CSc. Univerzita Karlova, Fakulta sociálních věd, katedra sociologie Institutu sociologických studií. U Kř́že 8, 15800 Praha 5, přechodně Pekařská 16, 15500 Praha 5. E-mail: hynek.jerabek@ gmail.com nebo hynek.jerabek@fsv.cuni.cz
} 
a usiluje o jeho vyústění do různých forem obohacení dosavadního poznání. Působení kolumbijského modelu sociologie i výsledky př́mých aktivit P. Lazarsfelda v rámci ovlivňování poválečného vývoje empirického sociálního výzkumu v Evropě je možno vysledovat v několika zemích západní Evropy. Často přitom narazíme na souvislosti s činnostmi, jež pomáhala prosazovat mezinárodní organizace UNESCO.

Tato studie si klade za cíl ukázat na modelovém prŕíkladu jedné země - konkrétně Norska - jak se šíril model kolumbijské sociologické školy a Lazarsfeldovy empirické sociologie v Evropě. Na tomto pozadí se pokusím odhalit významné aktéry a okolnosti, které byly podstatné pro institucionalizaci teoreticky zakotveného empirického sociologického výzkumu v uvedené zemi. Stat' se také snaží pojmenovat vlivy a faktory přispívající k úspěšnému replikování kolumbijské sociologické dílny právě v Norsku. Třetím, neméně důležitým cílem je pozornost věnovaná specifickému průvodnímu jevu šírení Lazarsfeldovy sociologie. Tím byl i v norském případě trénink v empirickém výzkumu jako př́má součást výuky. Budeme tedy sledovat zavádění teoreticky zakotveného empirického sociálního výzkumu v podmínkách Univerzity v Oslu a zde založeného Institutu pro sociální výzkum.

Norsko bylo jednou z prvních zemí, kde Paul Lazarsfeld po válce působil. Na pozvání rektora Univerzity v Oslu Otto Louse Mohra zde vyučoval podstatnou část zimního semestru 1948/49 a Norsko se tak stalo vůbec první evropskou zemí, v níž se podařilo během několika let (od počátků místních snah v roce 1947 do roku 1955) úspěšně prosadit a zavést Lazarsfeldovu metodologii v sociologii. Důležitou okolností vývoje přitom byla skutečnost, že se $\mathrm{v}$ př́ihodné době spojily snahy místních aktérů z řad mladých pracovníků a studentů Univerzity v Oslu a podpora Rockefellerovy nadace i Fulbrightova programu s Lazarsfeldem vedeným a jeho mladším spolupracovníkem Alenem Bartonem prosazovaným cílevědomým tréninkem empirického sociálního výzkumu. Tímto způsobem mohlo dojít k praktickému uplatnění všech naznačených snah ve výzkumném projektu. Nic z toho by se ovšem nepodařilo bez podpory místních podnikatelů a norského státu. To vše navíc v zemi, která neměla tradici předválečné sociologie, kde tudíž sociologie po válce de facto začínala. ${ }^{1}$

\section{Norsko po 2. světové válce a situace na Univerzitě v Oslu}

Podle norského historika sociologie Fredrica W. Thueho hned v říjnu 1945 představitel Rockefellerovy nadace John Marshall navštívil Oslo. Následně do své centrály podal velice příznivou zprávu: „Nadace považuje Norsko za jednu z evropských zemí, v nichž vypadá budoucí spolupráce jako nejnadějnějšíi [Thue 2006: 157]. Plánovaná spolupráce byla pro obě země velmi slibná - Američané si cenili vědců, kteří v Norsku vzdorovali německé okupaci po celou druhou světovou válku, a Norové očekávali spojené výhody internacionalizace, finanční podpory a intelektuálního partnerství [tamtéž].

Důležité bylo, že sama Rockefellerova nadace skutečně měla na spolupráci s poválečným Norskem zájem. Jednou z významných osobností norské vědy, která její představitele zaujala, byl filozof Arne Naess. Ten měl před válkou za sebou rok studia ve Vídni (rok studia strávil také v Paříži), kde se podrobně seznámil s myšlenkami Vídeňského kroužku,

1 Fredric W. Thue k tomu uvedl: „Ani uznání sociologie jako oboru, v němž bylo možno získat magisterský diplom v letech 1937-39 nebylo provázeno založením zvláštní katedry“ [Thue 2006: 245]. 
z jehož členů jej zřejmě nejvíce zaujal Otto Neurath a jeho pragmatické pojetí logického empirismu. V Oslu Naess graduoval disertací Erkenntnis und wissenschaftliches Verhalten (Poznání a vědecké chování) [Thue 2006: 136] a byl následně na místní univerzitě jmenován profesorem filozofie, což se odehrálo na podzim 1939, kdy mu bylo pouhých 27 let [Thue 2006: 133]. Během války patřil k výrazným osobnostem protifašistického odboje v akademickém prostředí Norska a hned po válce jej Rockefellerova nadace pozvala k návštěvě univerzit v USA.

S podporou A. Naesse začali studenti práv a filozofie usilovat o zavedení sociologie do výuky a společně s tím rovněž o zřízení profesury v oboru sociologie. Skupina studentů a mladších společenskovědních pracovníků Univerzity v Oslu měla velký zájem o empirický výzkum, jaký pro ně představoval model „survey“, jenž bylo možno najít na Kolumbijské univerzitě v New Yorku a v jejím výzkumném ústavu BASR. První výuky sociologické metodologie se skupina asi deseti či dvanácti vážných zájemců z řad studentů dočkala poprvé na jaře 1946, kdy profesor Art Sommerfelt, který se v listopadu 1945 vrátil ze San Francisca do Norska, začal v Oslu vyučovat výběrový kurz sociologické metodologie [Thue 2006: 246].

V té době zatím na tamní univerzitě stále ještě neexistovala sociologie jako vyučovaný obor, nebyl zde jediný profesor sociologie a sociologické zájmy projevující profesor Sommerfelt byl hlavním oborem lingvista. Ani fakulta sociálních věd či jakákoliv jiná podobně zaměřená fakulta zde neexistovaly, chyběla katedra sociologie a empirický výzkum v sociologii nebo př́buzných vědách se vůbec nepěstoval. Ustavení Fakulty sociálních věd na Univerzitě v Oslu, o které by tolik stáli mladí začínající badatelé a aktivní studenti, shodně odmítali představitelé vlastně všech jednotlivých oborů etablovaných na Historicko-filozofické fakultě: historie, klasické filologie, etnologie, etnografie, geografie, s výjimkou ekonomů a psychologů [Thue 2006: 248].

Univerzitní komise ustavená za účelem řešení tohoto problému dospěla po dvou letech, tedy v roce 1952, k závěru, že „sociologie, psychologie a politická věda nemají dostatečnou vědeckou váhu, aby mohly být zárukou úspěšného založení zvláštní fakulty“ [Thue 2006: 249]. Komise také vyjádřila autoritativní názor opírající se o zájmy citovaných disciplín, nebot’ „jakýkoliv pokus doplnit plánovanou fakultu dalšími disciplínami jako ekonomií, etnologií anebo etnografií by zpơsobil více problémů, než kolik by jich vyřešil“ [tamtéž]. Ekonomové si přáli zůstat součástí právnické fakulty, geografové a pedagogové dávali př̀ednost svému zařazení co nejblíže struktuře zohledňující jejich místo při výuce učitelù. Univerzita se tudíž rozhodla pro „zachování statu quo: žádnou sociálně-vědní fakultu a žádné posuny oborů v rámci existujícího fakultního systému“ [tamtéž]. Prosazení nového pojetí sociologie i politické vědy a jejich praktické užitečnosti musela proto nejprve napomoci intenzivní dlouhodobá spolupráce s americkými společenskými vědci, univerzitními pracovišti a výzkumnými nadacemi [Thue 2006: 250].

O takovou spolupráci jako první začali z výše naznačených důvodů usilovat nejmladší členové norské akademické obce - mladí asistenti a badatelé, doktorandi a studenti, jinak řečeno ti, kdo zatím zastávali marginální pozice v rámci národního akademického systému [tamtéž]. Nejaktivnější ze studentů přitom projevovali zájem o výuku praktických předmětů, které by je připravily k profesionálnímu provádění empirického výzkumu. Naštěstí hned v dubnu 1946 Rockefellerova nadace podpořila A. Naesse grantem ve výši \$ 14500 ten mu umožnil postupně v letech 1946-1951 vyslat z Norska pět mladých badatelů na 
renomované americké univerzity, aby zde hned po válce strávili několik měsíců nebo i celý akademický rok a seznámili se s pokroky svých disciplín [Thue 2006: 160].

Jedním z vybraných studentů byl Vilhelm Aubert. Tento čerstvý absolvent práv odjel do USA hned s Naessem na jaře 1946, poté strávil celý akademický rok na Kolumbijské univerzitě v New Yorku a jako postgraduální student sociologie zde navštěvoval přednášky a semináře Paula Lazarsfelda a Roberta K. Mertona. Ve zprávě Rockefellerově nadaci poté V. Aubert popsal své zkušenosti z aktuální výzkumné práce, kterou vykonával v Lazarsfeldově Bureau of Applied Social Research (BASR) spjatém s univerzitou, což mu poskytlo „Živou představu o tom, jak pracuje moderní vědecká instituce“ [Vilhelm Aubert Report 1947].

\section{Plán Erica Rindeho}

Na Kolumbijskou univerzitu do New Yorku přijel v listopadu 1946 na tříměsíční pobyt také Eric Rinde [Thue 2006: 253]. Toho Lazarsfeldovy semináře i sociální výzkum v podobě, jak zde byl prováděn, zaujaly natolik, že po návratu do Osla počátkem roku 1947 začal sám hledat podporu pro výuku sociologie a empirického výzkumu na Univerzitě v Oslu. Soustředil kolem sebe skupinu mladých lidí a společně ustavili sociologický akční výbor. Nebyl mezi nimi žádný profesor, pouze samí mladí badatelé, vyučující a zainteresovaní studenti. V úvodní řeči na zakládající schůzi akčního výboru formuloval E. Rinde tři hlavní úkoly skupiny: 1) propagovat sociologii ve veřejnosti a mezi potenciálními sponzory; 2) působit na univerzitní autority, aby vypsaly granty na sociologický výzkum a výuku; a 3) aby zahrnuly do rozpočtu na rok 1948 mzdu pro amerického hostujícího profesora [Thue 2006: 254].

E. Rinde měl zkušeného rádce v osobě Petera A. Muncha, norského vysokoškolského učitele, který byl dopodrobna seznámen s univerzitními mechanismy. P. Munch sice v té době právě emigroval do USA na univerzitu ve Wisconsinu, mohl však odtamtud svému dlouholetému studentovi předat cenné zkušenosti a rady. Podle něj jedinou účinnou metodou, jak překonat překážky a odpor vládnoucí univerzitní byrokracie, bylo prokázat se konkrétními výsledky sociologického výzkumu - pro obor bylo potřeba získat akademické uznání [Thue 2006: 254-5]. Naopak bylo rozhodně nezbytné vyhnout se cestám, jež by vyžadovaly byrokratické akademické schvalování [Letter from Peter A. Munch ... 1947].

Mobilizace norské veřejnosti, podporovaná masovými médii, našla nakonec podporu i na půdě norského parlamentu. Dlouho neobsazená pozice profesora pro teorii pracovních sil („theory of labor“), která byla dosud v působnosti právnické fakulty, byla v červnu 1947 z iniciativy univerzitní parlamentní komise přeměněna na obecnou profesuru sociologie, spadající pod Historicko-filozofickou fakultu Univerzity v Oslu. Univerzita na tento akt reagovala zařazením redefinovaného postu profesora sociologie do svého univerzitního rozpočtu pro rok 1948/49, a to bez ohledu na protesty právnické fakulty [Thue 2006: 256].

Nejdůležitější částí Rindova plánu však bylo pozvat jednoho z představitelů „kolumbijské“ sociologie jako hostujícího profesora na Univerzitu v Oslu. Jen takový představitel v USA pevně zakotveného oboru mohl zorganizovat kolektivní výzkumný projekt „který by mohl prokázat praktický význam sociologie a mohl působit jako katalyzátor pro její institucionalizaci“ [Thue 2006: 256]. Pro uskutečnění tohoto plánu ovšem chyběly peníze. 
Univerzitní představitelé nemohli přislíbit, že budou schopni financovat plat takového hostujícího profesora $\mathrm{z}$ běžného rozpočtu. Rinde znal situaci v USA, kde byly často prostředky pro sociální výzkum získávány z privátních zdrojů. Jak píše Thue, Eric Rinde „vytáhl eso z rukávu“. Již měsíc po schůzce sociologického akčního výboru mohl předstoupit před rektora univerzity Ottu Mohra s šekem na 15 tisíc norských korun „od anonymního dárce“. Šek měl být použit ke specifickému účelu - pozvání hostujícího profesora sociologie pro akademický rok 1947/48. Tím utajeným sponzorem byl Rindeho otec, Sigurt Rinde, úspěšný podnikatel v dřevařském průmyslu [Thue 2006: 256-7]. „Šek vybavil Erica Rindeho a jeho neformální akční výbor potřebnou autoritou. Rektora Mohra přesvědčilo jejich odhodlání a cílevědomost, ukázal dobrou vůli a osobně se významně angažoval v jejich záležitosti“ [Thue 2006: 257].

Pozvání amerického profesora by mohlo na Univerzitu v Oslu přinést model výzkumu z Kolumbijské univerzity. Nyní šlo už pouze o to, kdo konkrétně bude pozván a s jakým projektem se celá akce uskuteční. Formálně za sociologii na Historicko-filozofické fakultě stále ještě odpovídal profesor Sommerfelt, který zde jako jediný sociologii přenášel, přičemž zájemců o jeho přednášky postupně přibývalo. Podle zpráv V. Auberta zasílaných z Kolumbijské univerzity v únoru a v březnu 1947 přicházeli v úvahu Robert Lynd, spoluautor Middletownu, anebo Paul Lazarsfeld, zakladatel BASR. Sommerfelt - právě tak jako nezávisle na něm S. Holm - upřednostňoval Lynda, jehož epistemologická orientace by jim oběma lépe vyhovovala [Thue 2006: 258-9].

Jak píše G. Birkelundová, S. Holm studoval filozofii spolu s A. Naessem, strávil roční stáž v USA v univerzitním roce 1947-48 a později (1949) se stal prvním profesorem sociologie na Univerzitě v Oslu [Birkelund 2006: 54]. ${ }^{2}$ Byl to tedy S. Holm, kdo, pravděpodobně ve spolupráci s Ericem Rindem, připravil rektorův zvací dopis pro prof. Lynda. Poznámka, že druhý semestr by mohl př́padně v Oslu strávit jiný profesor, pokud by se Lynd nemohl uvolnit na celý akademický rok, byla nejspíš přičiněním Erica Rindeho. ${ }^{3}$ Díky spřízněným postojům zúčastněných aktérů byl dopis formulován natolik instrumentálně, že poskytl Lyndovi důležitý prostor pro alternativní návrh. Rektor doslova napsal: „Dozvěděl jsem se, že norští studenti sociologie, kteří navštěvovali kurzy profesora Lazarsfelda, si velmi pochvalovali jeho výuku" [Thue 2006: 260]. ${ }^{4}$

V okamžité odpovědi rektoru Mohrovi se Lynd omluvil, že bohužel nemůže přijet, avšak ujistil jej, že „vybrat Lazarsfelda by byla obdivuhodná volba ... protože převyšuje všechny ostatní v oblasti výzkumných metod a představuje ,nejlepší kombinaci představivosti a výzkumných zkušeností s jakou jsem se kdy setkal““ ${ }^{5} \mathrm{~F}$. W. Thue tedy z tohoto důvodu pasáž věnovanou prvním aktivitám Rindeho uzavřel slovy: „Půda pro ,operaci Lazarsfeld' byla tedy připravena..." [tamtéž].

2 Svere Holm získal grant Rockefellerovy nadace a studoval v letech 1947/48 antropologii v Yale u profesora Ralpha Lintona [Thue 2006: 267].

3 Je však možné, že sám Holm uvažoval alternativně o Lazarsfeldovi. Mluví pro to formulace, kterou uvádí G. Birkelundová, že Holm „psal nadšené dopisy prorektorovi Univerzity v Oslu, v nichž zmiňoval, že objevil podnětné výzkumné skupiny na Kolumbijské univerzitě, kde pracuje ,kouzelník Paul Lazarsfeld - člověk, který vytvořil nové formy výzkumu kamkoliv se podívášs" [Birkelund 2006: 55].

4 Letter from Rector Otto Lous Mohr to Robert Lynd, 4/22/1947, file: „Kr. 15000 til fremme av sosiologisk forskning ved Universitetet", jnr. 3068/48, central Archives, University of Oslo [Thue 2006: 260].

5 Letter from Robert S. Lynd to Rector Otto Lous Mohr. 5/3/1947, same file [tamtéž]. 


\section{Výběr výzkumného projektu a Lazarsfeldovy přednášky v Oslu}

Jak nakonec probíhala samotná akce, která zahrnovala pozvání hostujícího profesora z USA pro výuku empirického sociálního výzkumu, ustavení profesury pro sociologii na Historicko-filozofické fakultě Univerzity v Oslu, a rovněž vznik Institutu sociálního výzkumu? Všechny tyto tři proměny postavení sociologie v norském systému vysokoškolské výuky a výzkumu byly vzájemně propojeny, udály se ve vzájemných souvislostech a v časové následnosti. Byly přitom vázány na pouze částečně propojené zájmy zúčastněných aktérů. Všechno dohromady však jednoznačně vedlo k posílení vědecké prestiže sociologie v norském univerzitním systému. Došlo k navození postupné změny podoby sociologie směrem k empirickému zkoumání, což významně napomohlo k internacionalizaci norského sociálního výzkumu. Uvedené změny přispěly k propojení norské sociologie s empirickým sociálním výzkumem v USA a v tomto smyslu také vyznívá hodnocení G. Birkelundové: „První generace sociologů v Oslu měla strategické cíle pro svou vědeckou práci, byli trénováni $\mathrm{v}$ mezinárodním prostředí a také ve velké míře publikovali $\mathrm{v}$ zahraničí [Birkelund 2006: 57].

Pro rozvoj empirického výzkumu na Univerzitě v Oslu bylo třeba zvolit vhodné téma a vybrat projekt. S jedním z nápadů přišel S. Holm, jenž pocházel z norského venkova, přesněji ze zemědělsko-průmyslového městečka Sauda ze západního Norska. Zaujaly ho procesy industrializace a chtěl je studovat na př́kladu severo-norského městečka Mo i Rana, které se přímo před očima proměňovalo ze zemědělské komunity na moderní průmyslové město. Chtěl se podle vzoru studie Middletownu manželů Lyndových věnovat procesům kulturní změny [Thue 2006: 257]. Lazarsfeld, jenž byl nakonec zvolen jako „vyslanec Kolumbijské univerzity a její metodologie“, hledal projekt splňující současně několik požadavků důležitých pro to, aby se dostatečně projevily charakteristické rysy empirické sociologie. Projekt měl svým rozsahem vyžadovat zapojení většího počtu studentů a ti se při něm měli naučit terénní výzkumné práci. Bylo důležité, aby projekt zároveň odpovídal zájmům Norska. Měl přinést užitečné výsledky, které by transparentně ukázaly možnosti empirického sociálního výzkumu v norské společnosti.

Lazarsfeld předpokládal, že by v případě Norska mohlo být výhodné hledat podporu pro sociologický výzkum u norské výkonné státní moci, možná i proto, že v Norsku vládli sociální demokraté, místní „labour party“. Hlavní motivací pro tuto úvahu však byl značný rozdíl mezi Evropou a USA. V evropských zemích, a tedy též v Norsku, chyběla pravidelná spolupráce mezi výzkumnými agenturami a privátním sektorem, fungující v USA již řadu let. Nebyla zde významně přítomna ani pomoc filantropických nadací při provádění sociálního výzkumu, která se v USA rozvíjela už po několik desetiletí.

Lazarsfeld mohl využít vlastní předválečnou zkušenost z Vídně. Jeho největší výzkumy nesponzorovaly soukromé firmy, přestože založil Výzkumný ústav pro aplikovanou psychologii a ve správní radě této instituce zasedali vůdčí průmyslníci z Rakouska. Na výzkum Marienthalu přispěla vídeňská „Arbeitskammer“, částečně sociální demokracie a také Rockefeller Foundation. Výzkum rozhlasových posluchačů RAVAG byl financován tehdy monopolní, se zájmy státu propojenou, rozhlasovou společností „RAVAG“, tedy Radio Verkehrs AG. ${ }^{6}$ Podle Lazarsfeldových představ se v Norsku měla sociologie stát nástrojem

6 Podrobnosti viz [Jeř́bek 2014]. 
evaluace a poradenství akcí připravovaných a podporovaných vládou. Po řadě konzultací a úvah se Lazarsfeld rozhodl prosazovat takový projekt, jenž by svými očekávanými výsledky mohl a měl inspirovat norskou vládu a průmyslové kruhy k zájmu o sociologický výzkum a podnítit jeho budoucí finanční podporu.

Lazarsfeld v rozhovoru, který s ním vedla Joan Gordon v prosinci 1961, potvrdil aktivní úlohu mladých norských zájemců o empirický sociologický výzkum i jejich odhodlání založit výzkumný ústav a uvedl, že do Norska přijel vyučovat metody empirického sociologického výzkumu. Na závěr této části rozhovoru jednoznačně zdůraznil, že aktivní úlohu v celém procesu spolupráce sehrála norská strana. Na otázku: „jel jste do Norska vyučovat metody?" Joan Gordon ihned odpověděl: „Ano, strávil jsem celý semestr v Norsku. Norové se rozhodli založit institut pro sociální výzkum a požádali mě, abych to zorganizoval, a jel jsem tam v roce 1948. ... Norský výzkumný ústav sice měl být stejný jako ostatní, ale tam to bylo jiné, protože jsem nemusel nikoho přesvědčovat, tím říkám, že oni mě pozvali ..." [Joan Gordon 1961: 64-65].

Času na př́pravu bylo dost. Lazarsfeld totiž nedorazil ani na podzim 1947, ani na jaře 1948, nýbrž se s představiteli Univerzity v Oslu domluvil, že přijme pozvání k souvislému přednáškovému pobytu až pro podzim 1948. Téma projektu postupně uzrávalo, až získalo konečný tvar někdy v červnu 1948, kdy se Lazarsfeld setkal s V. Aubertem, S. Holmem a dvěma norskými ekonomy v Seattlu na katedře sociologie u George Lundberga. Obecné téma „social planning and free enterprise“ Lazarsfeld ještě konzultoval s představiteli Rockefellerovy nadace a se svými kolegy na Kolumbijské univerzitě, zejména s R. S. Lyndem [Thue 2006: 267-9]. Téma bylo pro Norsko vhodné, jak napsal autor disertace $\mathrm{k}$ tématu norského plánování $\mathrm{A}$. Barton, protože právě v této zemi bylo možno najít „jeden z nejrozvinutějších systémů plánování ze všech zemí mimo sféru sovětského vlivu“ [Barton 1957: ii]. Také Marshallův plán, který byl přijat americkým kongresem v březnu 1948 - tedy jen tři měsíce před konečným rozhodnutím o podobě norského projektu -, přispěl k aktuálnosti problematiky. Podle Michaela J. Hogana předválečný New Deal inspiroval Marshallův plán „přestavět Západní Evropu podle vzoru Ameriky“ [Hogan 1987: 427].

Pro Lazarsfelda bylo zajímavé zabývat se evropskou zemí, kde vládne sociální demokracie. Podle A. Bartona „Lazarsfelda zvlášt zajímalo zjistit, co dokáže sociálně demokratická vláda, když je u moci“ [Barton 1998: 72]. Toto téma pro něj bylo natolik důležité a slibné, že požádal svou první manželku Marii Jahodovou, která měla za sebou kariéru významné předválečné sociálně demokratické političky, aby v dopise požádala svého přítele, tajemníka Norské strany práce Haakona Lie, aby se v Oslu s Paulem Lazarsfeldem sešel. Přátelský dopis napsaný 30. června 1948 byl odeslán s dostatečným předstihem před Lazarsfeldovou cestou a uváděl nejenom to, že Lazarsfeld přijede brzy přednášet na Univerzitu v Oslu, ale také že se jedná o levicově zaměřeného vědce, předválečného vídeňského sociálního demokrata, jenž se stále zajímá o problémy sociálních demokratů v Evropě a v Norsku [Jahoda 1948]. Marie Jahodová napsala: „Vím, že se [Lazarsfeld] těší na svou stáž v zemi, kde ,labor ' je aktivnější sociální síla než v USA“ a zakončila svůj dopis srdečnými slovy: „Neubírala bych Vám váš čas, kdybych si nebyla jista, že Vás i Dr. Lazarsfelda potěší, že se vzájemně poznáte“ [tamtéž].

Pro naše posouzení vývoje celého procesu „institucionalizace empirického sociálního výzkumu“ v Norsku byla nesmírně důležitá aktivita norských studentů a mladých 
účastníků Lazarsfeldových kurzů na Univerzitě v Oslu. Patrně nejdůležitějším dokladem jejich vysoké motivovanosti a porozumění smyslu celé Lazarsfeldovy akce bylo vytištění „Training guide“ (Učebního manuálu) pro konstrukci a používání dotazníku. Tento velmi podrobný školící materiál o šedesáti stranách s dalšími desítkami stran prŕíkladů byl na Kolumbijské univerzitě již prověřený a patrně zde běžně sloužil pro výuku a instruktáž studentů. Z vytištěné verze školícího textu uchovávané v archivu Kolumbijské univerzity zřetelně vyplývá, že to byla „Oslo Edition“, tedy soubor manuálů vytištěných na Univerzitě v Oslu. Byl zjevně používán studenty kurzů, které probíhaly ve školním roce 1948/49 na této univerzitě. Šlo o tréninkový manuál založený na zkušenostech kolumbijského BASR a Lazarsfeld se rozhodl využít jej při výuce na Univerzitě v Oslu. Titulní strana manuálu prozrazuje, že byl vytištěn pod hlavičkou studentské samosprávy na Univerzitě v Oslu (Universitetets Studentkontor) v roce 1948, tedy v době školení. Z toho lze odvodit také spojitost se skupinou studentů vedených Ericem Rindem [Training Guide 1948].

Další akcí významnou pro zdar celé mise byla realizace promyšleného plánu zapojit do „výukového sabbaticalu“ na Univerzitě v Oslu Lazarsfeldova spolupracovníka z katedry sociologie Kolumbijské univerzity a BASR. V Oslu spolu s ním totiž působil jeho doktorand Allen Barton. Přicestovali společně již na podzim 1948, jak to vyplývá to z Lazarsfeldova dopisu rektoru O. Mohrovi z počátku října 1948, v němž popisoval Allena Bartona „jako skvělého mladého sociologa a zkušeného statistika a tazatele“ [Thue 2006: 269]. A Lazarsfeld to navíc prímo potvrdil v rozhovoru s Joan Gordon v prosinci 1961. Uvedl v této souvislosti následující: „Jel jsem tam [do Osla] v roce 1948. Vzal jsem Bartona s sebou, a on tam zůstal o šest měsíců déle“ [Joan Gordon 1961: 64].

Allen Barton, jemuž bylo v té době 25 let, byl dostatečně zkušený na to, aby vedl semináře v rámci Lazarsfeldova kurzu a dohlížel na provádění empirického výzkumu podle přijatého projektu. Lazarsfeld dokonce sám př́mo požádal Dr. Pendletona Herringa, ředitele Rady pro sociálněvědní výzkum v USA (Social Science Research Council), aby tato vlivná instituce ze svých prostředků financovala stipendium umožňující Bartonův celoroční pobyt v Oslu [Letter PFL to SSRC 1948]. A byl to také Barton, kdo převzal po Lazarsfeldově odjezdu záruku a dohled nad projektem sociologického a ekonomického plánování v Norsku. Jeho náměstky v projektu byli profesor Svere Holm a později slavný politický vědec Stein Rokkan. Spolu s norskými spolupracovníky publikoval Barton několik článků a zpráv z výzkumu. Dokladem jeho ztotožnění s problematikou je také jeho disertační práce s titulem „Sociologické a psychologické problémy ekonomického plánování v Norsku" (Sociological and Psychological Problems of Economic Planning in Norway) [Barton 1957].

Lazarsfeld přednášel v Oslu od 2. záŕí do poloviny ř́ína, poté odjel na akci UNESCO, a po návratu z Paříže ještě vyučoval do konce listopadu 1948. Pak ale musel plánovaný celosemestrální pobyt zkrátit pro neodkladné povinnosti v New Yorku. Na schůzku představitelů několika západních zemí do Paříže odjel Lazarsfeld podle dlouho předem domluveného plánu, aby se zde účastnil př́pravy sociálního projektu v rámci UNESCO. Zároveň se v Pařiži angažoval v iniciativě, jež vedla záhy nato k založení Mezinárodní sociologické asociace (ISA). A při této prŕležitosti použil Lazarsfeld svého vlivu, aby se nějak odměnil Ericu Rindemu za inciciativu, která vyústila v jeho přednáškový pobyt v Oslu. Z Osla do Paříže cestoval právě spolu s Ericem Rindem, a tam se také oba setkali s Arne Naessem a Steinem Rokkanem, kteří zde byli aktivní ve svých funkcích vykonávaných v rámci 
UNESCO.7 V Paříži se při prŕležitosti jednání na půdě UNESCO sešel dostatek vysoce postavených představitelů sociologie z několika západních zemí, a tak zde 14. ř́inna mohli projednat společný zájem na vzniku mezinárodní organizace, jež by zastupovala sociology většiny nebo všech západních zemí navenek a koordinovala jejich mezinárodní spolupráci [Platt 1998: 14]. Schůzka významných sociologů několika zemí umožnila Paulu Lazarsfeldovi podpořit Erica Rindeho jako navrženého sekretáře přípravného výboru vznikající Mezinárodní sociologické asociace (ISA) [Thue 2006: 283]. Tento mladý norský právník měl zároveň podporu Nora Arvida Brodersena předsedajícího schůzi jako vedoucí odboru sociálních věd UNESCO - a samozřejmě také Lazarsfelda [tamtéž: 284-285]. Rinde, který se zatím nemohl prokázat významnými sociologickými hodnostmi akademického rázu, hned rok poté (5.-10. září 1949) již organizoval v Oslu první ustavující kongres ISA. Zúčastnili se ho zástupci jednadvaceti zemí (Rakouska, Belgie, Velké Británie, Kanady, Kuby, Dánska, Egypta, Finska, Francie, Indie, Izraele, Itálie, Nizozemí, Norska, Polska, Švédska, Švýcarska, Turecka, Uruguaye a USA). Přítomen byl rovněž Leopold von Wiese, ale ne jako oficiální zástupce Německa [Platt 1998: 16].

\section{Další osudy Lazarsfeldova projektu na Univerzitě v Oslu}

Pravdou je, že proměna sociologie na Univerzitě v Oslu neprobíhala tak rychle, jak by si to Lazarsfeld patrně přál. Zásadní aktivity však byly zahájeny a měly přinášet své ovoce teprve postupně. Iniciativní Eric Rinde, jeden z nejdůležitějších aktérů první etapy procesu postupné proměny sociologického Norska, časem ustoupil do pozadí. Stál však s velkou pravděpodobností za praktickou realizací tisku tréninkových materiálů a zřejmě se také podílel na výzkumné činnosti projektu, který započal Lazarsfeld a v němž pokračoval Barton. V dopise z 27. září 1949 se Lazarsfeld Rindovi omlouval, že pravděpodobně zvolili příliš rozsáhlý projekt a ten možná celý neskončí kompletním úspěchem [Letter PFL to Rinde 1949]. Hodnocení projektu jako v zásadě neúspěšného lze najít i v článku G. Birkelundové. Napsala, že Lazarsfeld „navrhl rozsáhlý projekt uspořádání politik pro norskou veřejnou správu, který měl norskou sociologii využít jako nástroj sociálního inženýrství. Projekt však z politických důvodů nebyl nikdy spuštěn" [Birkelund 2006: 56]. Přesněji řečeno sběr dat i jejich analýza proběhly a využil je např́klad A. Barton ve své disertační práci [Barton 1957]. K sociotechnickým zásahům ovšem nedošlo.

Avšak posouzení, jak úspěšná byla realizace projektu, nebylo samo o sobě významné pro hodnocení správnosti rozhodnutí, jaký projekt pro Norsko vybrat, nebot' pro Lazarsfelda měl především instrumentální úlohu. Sloužil v procesu implementace empirického sociálního výzkumu do evropské - v tomto případě do norské - sociologie. Z Lazarsfeldova pohledu byl projekt zvolen účelně. Sociologičtí výzkumníci v Norsku jej skutečně připravovali a již při tom se naučili spoustu dovedností. Byl také zahájen a několik měsíců probíhal - to vyplývá z realizace disertační práce A. Bartona na téma analyzovaného projektu. A to, že v posledku nedospěl do fáze, v níž by měl sloužit k řízení společenských

Tore Slaatta o spolupráci Arne Naesse a Steina Rokkana s UNESCO uvádí: „V létě 1948 před příjezdem Lazarsfelda do Osla, Naess a jeho asistent Stein Rokkan odjeli do Paříže, kde se v centrále UNESCO podíleli na přípravě prvního UNESCO „,,projektu demokracie‘ jako kombinované historicko-sémantické analýzy procesu používání a diskuse pojmu demokracie spolu s dotazováním názorů elit na to, jak používají pojmů ,svoboda‘ a ,demokracie““ [Slaatta 2016: 180]. 
procesů, nebylo pro Lazarsfelda př́liš důležité. Právě to se ostatně snažil vysvětlit v dopise Ericu Rindovi. Podle Rindových budoucích aktivit v roli ředitele prripravovaného centra mladý výzkumník vše pochopil správně. Lazarsfeld soudil, že vlastně ani nebyla lepší volba, jeho cílem totiž bylo přimět v procesu výuky a tréninku co nejvíce mladých aktérů sociologie, aby se prakticky angažovali v empirických výzkumných aktivitách. Chtěl jim přiblížit atmosféru prožívaného výzkumného projektu ve stejné podobě, jak ho zakoušeli jeho doktorandi a studenti v rámci praktického školení účastí na práci BASR. Kdyby byl projekt jednoduchý, a tudíž také asi úspěšnější, nezapojilo by se do něj tolik studentů a nevyzkoušeli by si na něm všechny potřebné etapy a procedury, z nichž velký projekt vždy sestává. Lazarsfeld podle názoru Fredrica Thueho jen podcenil minimální zkušenost norských studentů a doktorandů s jakoukoliv formou kolektivně organizovaného empirického sociálního výzkumu. Jeho projekt proto působil na mladé nezkušené aktivisty v Oslu coby „léčba šokem“ [Thue 2006: 278]. Norská sociologie si vlastně prorážela cestu podobně jako pět až deset let předtím empirický sociální výzkum v USA.

Také pozornost, kterou Lazarsfeld vzbudil v norských médiích, měla svou instrumentální hodnotu. Americké prezidentské volby se konaly v listopadu 1948, právě v době, kdy byl Lazarsfeld na Univerzitě v Oslu. Napsal tehdy novinový článek k těmto volbám, o němž G. Birkelundová poznamenala: „Lazarsfeld, jeden z vedoucích světových expertů na sociální průzkumy, první americký sociolog v Oslu, se dostal do titulků hlavních zpráv v novinách" [Dagbladet 1948]. Hned svým prvním, trochu provokativním novinovým článkem $\mathrm{s}$ fotografiemi amerických kandidátů na prezidenta, upoutal Lazarsfeld pozornost norských čtenářò. A v dalším článku z 9. 11. 1948 G. Birkelundová poznamenala: „... po prezidentských volbách v USA, měl vysvětlit, proč se ve svých předpovědích mýlil ..." [Birkelund 2006: 56-57]. Teprve ve druhém novinovém článku bylo zveřejněno foto samotného profesora Lazarsfelda [Birkelund 2006: 58]. A on mohl využít vzbuzeného čtenářského zájmu norských voličů k vysvětlení, jak vypadá práce sociologa př̀i provádění předvolebních průzkumů. Potřetí zaujal Lazarsfeld norská masová média, když vyjednával s generálním ředitelem norského státního rozhlasu (NRK) Kaare Fostervollem o monitorování postojů a preferencí norských posluchačů rozhlasu. Jeho přesvědčil, avšak celé vedení norského rozhlasu se tenkrát ještě postavilo proti. V deníku Verdens Gang pak 17. listopadu 1948 vyšel s Lazarsfeldem rozhovor, takže měl opět př́ležitost zdůraznit své priority spočívající ve výzkumné orientaci sociologie. Navíc zde byla na úvodní straně otištěna i Lazarsfeldova karikatura s typickým doutníkem v ruce [Verdens Gang 1948] [srov. Slaatta 2016: 178-179]. Jejím autorem byl slavný norský karikaturista Salo Grenning, známý pod pseudonymem PEDRO. ${ }^{8}$ Lazarsfeld od něj následně získal ještě jednu svou karikaturu s datem 18. 11. 1948 a ta je nyní uložena v archivu Kolumbijské univerzity [Karikatura 18. 11. 1948].

Když Lazarsfeld koncem listopadu 1948 odjel z Osla, měl jen omezené možnosti, jak kontrolovat další průběh započatých procesů. Jeho „vyslancem v Oslu“ byl A. Barton, který se evidentně staral o osud výzkumného projektu a pravděpodobně i o co největší zapojení studentů sociologie Univerzity v Oslu do jeho průběhu. Úloha Erica Rindeho v projektu byla úměrná jeho roli a postavení na univerzitě - mohl podrobně a nezaujatě informovat Lazarsfelda o pokrocích jednotlivých prací a zároveň aktivizovat svoji skupinu

8 Viz Wikipedia [Salo Grening]. 
zaangažovaných studentů, kteří stáli na začátku akce. „Odměnou“ za vynaloženou práci mu patrně bylo především zapojení do procesu internacionalizace norské sociologie, což bylo pro tuto chvíli hlavním vkladem do jeho budoucí kariéry.

V záŕí 1949 - jak bylo v Paříži dohodnuto - zorganizoval Rinde první kongres nově založené mezinárodní sociologické asociace. F. Thue informoval, že „to bylo na ustavujícím kongresu Mezinárodní sociologické asociace ISA, kde došlo k Rindeho jmenování sekretářem a kde byl prezidentem ISA zvolen profesor Louis Wirth z Chicaga" [Thue 2006: 353]. Podle Birkelundové to byl Lazarsfeld, kdo navrhl Erica Rindeho „jako prvního tajemníka a hospodáře (secretary/treasurer) ISA. A tak se sekretariát ISA v prvním období po založení nacházel v Oslu, v Institutu pro sociální výzkum, v letech 1950-1953“ [Birkelund 2006: 57] [srov. Platt 1998: 15-17].

Za Lazarsfeldovy účasti byly nastartovány některé procesy, které pokračovaly i po jeho odjezdu z Osla. Pokud šlo o zapojení do procesu internacionalizace, Rockefellerova nadace neztratila ze zřetele svou orientaci na Norsko jako na jednu z nejnadějnějších zemí západní Evropy. Nadále měla zájem na ovlivňování norské sociologie prosazováním praktických zájmů amerických nadací a jejich důrazu na empirický sociální výzkum a jeho komparativní euroamerický aspekt. Téměř stejně to hodnotili jak Thue, tak i Birkelundová, která citovala z jeho v norštině publikovaného článku z roku 1990: „Marshallův program ... pro přestavbu evropské sociální vědy by nebyl možný bez amerických výzkumných nadací, jako byly Fulbrightův Program, Rockefellerova nadace a Fordova nadace. Ty poskytovaly významné zdroje pro tyto účely“ [Birkelund 2006: 56].

$\mathrm{K}$ řečenému je však třeba doplnit ještě druhý, neméně důležitý pohled. Dosažení cílů transformace evropské sociologie směrem k mezinárodně úspěšné empiricky zaměřené vědecké disciplíně mělo také druhou podmínku a jen při jejím splnění mohlo být masivní financování z prostředků amerických nadací i realizace dobře promyšlených projektů efektivní a úspěšné. Na straně př́ijemců těchto prostředků museli být aktivní zájemci a jejich snahy provázené pochopením pro zavádění př́ílušných pokrokových nástrojů společenskovědního výzkumu. Tak tomu bylo právě v případě Norska, kde Arne Naess, Vilhelm Aubert, Eric Rinde, Svere Holm, Stein Rokkan a desítky dalších chápali smysl akcí a opravdu aktivně přiložili ruku $\mathrm{k}$ dílu. Ale totéž se nepodařilo v jiných evropských zemích. Přibližně stejné, ne-li větší finanční prostředky, vynaložily americké nadace o několik let později v Rakousku. Rovněž těmto snahám a aktivitám velmi ochotně pomáhal na svět Paul Lazarsfeld, výsledky však bohužel zdaleka neodpovídaly vynaloženým lidským a finančním nákladům [srov. Fleck 2000; 2017]. Naprosté většině rakouských aktérů, kteří se stali př́jemci nemalých benefitů zprostředkovaných americkými nadacemi, chyběla motivace ke změně a postrádali zájem naučit se novým metodám sociologické práce [tamtéž]. Ve srovnání s neúspěšným Rakouskem je možno tudíž Norsko považovat za šampióna této sociologické transformace.

\section{Institut pro sociální výzkum 1949-1955}

Protože cesta ke vzniku fakulty sociálních věd neměla šanci najít dostatečnou podporu, zainteresovaní aktéři norské sociologie se pokusili hledat možnosti, jak ustavit Institut pro sociální výzkum. Protože univerzita nenabídla finance pro provoz takového útvaru v rámci univerzitního uspořádání, bylo třeba hledat jiné možnosti. V praxi to znamenalo najít pro 
institut financování a vyřešit jeho vazby na další instituce norské vědy a vysokého školství [Thue 2006: 337nn.].

Studentská iniciativa, která vedla k naplánování financí do rozpočtu univerzity, a tedy fakticky ke slibu inaugurace prvního profesora sociologie, se projevila očekávaným způsobem. Prvním profesorem sociologie na Univerzitě v Oslu se stal ve školním roce 1948/49 Svere Holm. Byl nejblíže ke jmenování již před započetím Rindovy akce a jeho stipendijní pobyt v USA na jaře 1948 i časté kontakty s Lazarsfeldem a dalšími americkými sociology mu k získání profesury jistě také napomohly [Thue 2006: 339].

Dalším hostujícím profesorem po Lazarsfeldovi se stal sociální psycholog David Krech, který přijel do Osla koncem srpna 1949 a kritizoval Lazarsfeldův projekt norského plánování, udržovaný při životě díky aktivitám A. Bartona a E. Rindeho [Thue 2006: 339]. David Krech měl svou vlastní výzkumnou agendu a pustil se v Oslu do projektu nacionalismu spolu s filozofičtěji orientovanými partnery. Jeho dalším cílem bylo, aby přesvědčil Erica Rindeho, že nejlepší řešení pro výzkumný ústav by spočívalo v založení soukromého Institutu pro sociální výzkum mimo univerzitu. Na hledání východiska se tehdy podíleli David Krech, Eric Rinde, Vilhelm Aubert, Svere Holm a Arne Naess [Thue 2006: 340]. Přitom Sigurt Rinde, Ericův otec, nabídl, že se pokusí získat finanční podporu dalších norských průmyslových firem. Pokud budou vyřešeny právní okolnosti daňových odpisů a zajištěna dlouhodobější perspektiva zakládané instituce, byl ochoten zvýšit svůj příspěvek a zajistit podporu dalších průmyslových korporací [tamtéž].

Kromě finančního zajištění - zpočátku především ze soukromých zdrojů - bylo třeba akademické podpory pro institucionalizaci sociologie i pro udržení chodu nově vytvořeného institutu. V roce 1949 byla v Norsku založena Národní výzkumná rada (NAVF), jejímž záměrem bylo podporovat základní výzkum, a to i ve společenských vědách. Druhou strategickou oporou vznikajícího institutu měl být Fulbrightův výměnný program (Fulbright Exchange Program). G. Birkelundová tento vývoj nejen zmínila, ale také pozitivně hodnotila: „V následujících letech byl ustaven program návštěv zahraničních profesorů z USA financovaný Fulbrightovou nadací. Zdá se, že Oslo bylo prvním evropským městem, které bylo zahrnuto do tohoto programu, a řada amerických sociálních vědců navštívila Oslo“ [Birkelund 2006: 56]. Vyjmenovala slavné profesory: „Po Paulu Lazarsfeldovi navštívili Oslo David Krech, Herbert Hyman, Daniel Katz, Talcott Parsons a další koncem čtyřicátých a počátkem padesátých let“ [Birkelund 2006: 64]. K samotnému založení výzkumného ústavu F. Thue napsal: „I když všechny detaily týkající se organizace vznikajícího institutu nebyly ještě zcela vyřešeny, pětičlenná čerstvě jmenovaná rada prohlásila 9. února 1950 Institut pro sociální výzkum za oficiálně založený“ [Thue 2006: 344].

Ve výše citovaném rozhovoru s Joan Gordon Lazarsfeld uvedl významné podrobnosti týkající se úspěšného financování Institutu sociálního výzkumu v Oslu - a v jeho slovech cítíme respekt k této instituci i ke skutečnosti, že se jako první začlenila do euroamerické spolupráce: „Existuje dosud, a je jedním z několika skutečně uznávaných pracovišṫ. Po pravdě řečeno, vlastně tu udržují dobrou tradici. Monopolizovali peníze z Fulbrightovy nadace a, abych nezapomněl, mají státní loterii a část $\mathrm{z}$ výtěžku této státní loterie je vyhrazena pro sociální výzkum, takže institut velmi prosperuje. Každým rokem jsou zde jeden nebo dva Američané. Každý, koho znáte - Hyman zde strávil rok, Dan Katz, prakticky všichni empiricky orientovaní výzkumníci“ [Joan Gordon 1961: 64-65]. Bylo totiž předjednáno, že v prvních třech letech fungování Institutu sociálního výzkumu v Oslu bude 
Fulbrightův program každoročně vybírat amerického profesora a financovat jeho roční pobyt s tím, že v prvních letech bude vždy tento profesor zastávat roli výkonného ředitele institutu. Financování pobytu Davida Kreche ${ }^{9}$ přešlo v druhé části jeho působení v Norsku právě na Fulbrightův program [Thue 2006: 340].

Bylo dále třeba vyřešit rovněž vztah mezi katedrou sociologie, jíž nyní vládl nově jmenovaný profesor sociologie S. Holm, a institutem. Ještě jednou do situace vstoupil radou de facto však intervencí - Paul Lazarsfeld. Jeho názor, opřený o zkušenosti z New Yorku, byl vyjádřen doporučením rektoru Mohrovi, aby výzkumný ředitel institutu tvořil protiváhu teoreticky zaměřenému vedoucímu katedry sociologie Sveru Holmovi. ${ }^{10}$ Potenciální problém, v nějž se mohla dualita situace vyostřit, když na Univerzitě v Oslu působila nově založená katedra sociologie a zároveň v rámci sociologie vznikalo výzkumné pracoviště financované z mimouniverzitních zdrojů, alespoň po formální stránce vyřešil S. Holm. Osobně všechny ujistil, že ,jeho katedra se soustředí na základní výuku sociologů, zatímco institut bude představovat centrum pokročilého amerického výzkumného tréninku a rozsáhlých výzkumných projektů“" [Thue 2006: 342].

Významný vliv na institutu si stále drželi Vilhelm Aubert a Eric Rinde. První z nich byl na náklady Rockefellerovy nadace vyslán na okružní studijní cestu po renomovaných výzkumných centrech a významných amerických univerzitách. V létě 1950 tak navštívil National Opinion Research Center (NORC) Chicagské univerzity, The Institute for Social Research (ISR) (Institut sociálního výzkumu Michiganské univerzity v Ann Arbor), Cornellovu Univerzitu a The Bureau of Applied Social Research (BASR) na Kolumbijské univerzitě v New Yorku. Po svém návratu předložil V. Aubert velmi kritickou zprávu Radě Institutu pro sociální výzkum, v níž upozornil na rizika související v navštívených výzkumných centrech s externím financováním. To podle Auberta vedlo a nadále vede k uzavírání vědecky triviálních kontraktů, což brání kumulativnímu vědeckému poznání. Rada institutu přijala jeho varování s př́slibem vyvážené politiky ve vztahu k teoriím i výzkumným aktivitám [Thue 2006: 348].

Materiální zabezpečení a provozní podmínky institutu se postupně zlepšovaly. V roce 1951 se Institut pro sociální výzkum přestěhoval do nové budovy a získal kvalitní vybavení výpočetní technikou a dostatečné prostory pro výzkumníky i sekretariát [Thue 2006: 345]. Vedení institutu prošlo také řadou vývojových kroků a personálních změn. Eric Rinde významný iniciátor procesů institucionalizace a internacionalizace empirického sociálního výzkumu v Norsku - si dlouhodobě držel významné administrativní pravomoci, at již formálně či neformálně. Jeho pozice byla zajištěna mimo jiné zainteresovaností institutu na finančních zdrojích, které byly v nezanedbatelné míře pod kontrolou jeho otce Sigurta Rindeho. Když skončilo dohodnuté období, během nějž byli výkonní ředitelé „dosazováni“ Fulbrightovou komisí z řad amerických hostujících profesorů, pravděpodobně tedy v roce 1952 nebo 1953, byl výkonným ředitelem jmenován Aubert. Rinde byl pověřen zajištováním administrativních záležitostí. V následujícícm období se o vedení dělili Vilhelm Aubert, Harald Ofstad a Stein Rokkan [tamtéž].

9 „[Professor Krech] byl původně pozván na základě soukromých prostředků zabezpečených otcem Rindeho [Sigurtem Rindem], avšak jeho plat byl později kryt novým programem a Krech se stal jedním z prvních ,Fulbright profesorů na Univerzitě v Oslu“" [Thue 2006: 340].

10 [Letter PFL to Rector 1949] Letter from Paul F. Lazarsfeld to Rector Otto Lous Mohr, October 10th 1949, in Coucheron-Jarl's Papers, Institute for Social Research Archives. 
Tato po sobě následující opatření rozdělující pravomoci byla posléze „nahrazena daleko jednoznačnějším uspořádáním, když byl Rinde formálně ustanoven ředitelem institutu v roce 1955, spojily se organizační a vědecké vedoucí funkce, a to pomohlo upevnit institut jako aktivní intelektuální společenství [tamtéž]. Závěrem je možno při pohledu na tuto etapu vývoje konstatovat, že někdy v polovině 50 . let, jinak řečeno v době, kdy byl již ředitelem Eric Rinde, „,institut zvýraznil své zapojení do výzkumného tréninku doktorandských studentů a Institut pro sociální výzkum se ve skutečnosti stal sociálněvědní výzkumnou akademií a tréninkovým centrem organicky propojeným s Univerzitou v Oslu“" [Thue 2006: 351].

\section{Závěr}

Předložená studie si kladla za cíl posoudit okolnosti a najít aktéry, díky nimž došlo v poválečném období k zavedení empirického sociologického výzkumu v jedné evropské zemi - v Norsku. Byli v ní vyjmenováni významní účastníci tohoto procesu, v prvé řadě místní badatelé, mladí výzkumníci a studenti Univerzity v Oslu. Ti se inspirovali aktivitami kolumbijské sociologické dílny založené několik let předtím Paulem Lazarsfeldem a známé jako BASR. Dalšími velmi důležitými spolutvůrci úspěchu tohoto „sociologického dobrodružství 'byly Rockefellerova nadace a Fulbrightův Program. Tyto dvě americké instituce štědře financovaly aktivity zmíněných mladých lidí a pozvaných hostujících profesorů. Po poradě s odborníky, kteří se podrobně seznámili se situací na místě, jejich pracovníci promyšleně rozhodovali o alokaci poskytovaných prostředků. Třetí - a to zdaleka ne zanedbatelnou - skupinu aktérů představovali norští průmyslníci a v jejich čele Sigurt Rinde, otec tehdejšího studenta Erica Rindeho, který stál u zrodu promyšleného plánu, jak v Norsku zavést trénink empirického sociologického výzkumu. Rychlé poskytnutí startovní investice, ale i pružné a ochotné navyšování objemu těchto prostředků norskými průmyslníky podle vývoje situace, zabezpečilo, že dobře míněné plány byly prakticky proveditelné. Ochota rektora Univerzity v Oslu Otto Louse Mohra podpořit ve správnou chvíli iniciativní aktivity členů akademické obce, a to i přes možnou nevůli konzervativní části univerzity, byla také velice potřebnou součástí mechanismů, jež napomohly úspěchu celého procesu.

Nezanedbatelnou úlohu sehrála rovněž současně probíhající organizační opatření pod dohledem představitelů norské vědy, kteří včasným založením Národní výzkumné rady (NAVF) v roce 1949 zajistili podporu základního výzkumu také ve společenských vědách. Je třeba zároveň připomenout úlohu demokratických institucí norské společnosti - byla to příslušná parlamentní komise, která připravila podmínky pro jmenování prvního profesora sociologie. Lazarsfeldem zvolené téma výzkumného projektu zdůraznilo využití sociologie při řízení státu a tím posílilo pozici vládní strany, jíž toto směřování vyhovovalo. V neposlední řadě lze ještě upozornit na roli Marie Jahodové a její přímluvu za Paula Lazarsfelda u Haakona Lie, tajemníka vládnoucí Norské strany práce.

Nesmíme však zapomínat na muže, který stál občas v pozadí a jindy se ocital přímo na scéně, když pružně kontroloval a koordinoval probíhající procesy s cílem rozšiřit model vědeckého empiricky zaměřeného sociologického výzkumu v Evropě, totiž na samotného Paula F. Lazarsfelda. Dokázal inspirovat důležité osoby v čele amerických institucí podporujících spolupráci s poválečnou Evropou k pomoci tam, kde to bylo zapotřebí. Neváhal 
použít svého vlivu při rozhodování o udělení důležitého stipendia svému nejbližšímu spolupracovníkovi v Norsku Allenu Bartonovi. Dále jeho aktivity měly význam v rozvoji internacionalizace sociologického výzkumu. Účastnil se jednání významných sociologů na půdě UNESCO v Pařiži v říjnu 1948 a spolupřipravoval tak založení Mezinárodní sociologické asociace (ISA). Ovlivnil rovněž rozhodnutí, aby Eric Rinde získal důležitý post klíčového organizátora prvního ustavujícího kongresu ISA v Oslu. Projevil tím vděk iniciátorovi svého přednáškového pobytu na Univerzitě v Oslu. A byl to právě Rinde, osvědčený organizátor ustavujícího kongresu ISA v Oslu, kdo byl v září 1949 po zásluze jmenován prvním vědeckým tajemníkem a hospodářem (secretary/treasurer) této mezinárodní asociace na první čtyřleté období let 1950-1953. Tato prestižní funkce pak mimo jiné stála u zrodu jmenování Erica Rindeho do funkce ředitele Institutu sociálního výzkumu v roce 1955. V neposlední řadě přispěla rozvoji poválečné empirické sociologie v Norsku také Lazarsfeldova schopnost zviditelnit se v médiích, která pomohla naladit pozitivní atmosféru v norské společnosti.

Z pohledu na začátku definovaných cílů tohoto článku je možno závěrem konstatovat, že aktivní prosazování metodologie kolumbijské sociologické školy a Lazarsfeldova modelu empirického sociálního výzkumu v Norsku v letech 1947-1955 bylo úspěšné. V Oslu se díky úsilí Paula Lazarsfelda a jeho kolegů podařilo, společně s norskými aktivními výzkumníky, místními průmyslníky a s podporou Rockefellerovy nadace, Fulbrightova programu i norské státní administrativy, ustavit Institut sociálního výzkumu při Univerzitě v Oslu, a tím vlastně vytvořit repliku Lazarsfeldova The Bureau of Applied Social Research při Kolumbijské univerzitě v New Yorku v jeho evropské mutaci. Viděno z historické perspektivy to rozhodně nebylo málo.

\section{Poděkování}

Tento článek byl podpořen Grantovou agenturou České republiky Grant č. 18-13807S „Lazarsfeldova metodologie a její využití v politické sociologii a komunikačních studiích v letech (1950-1976)“ a řešen byl také v rámci programu Progres Q15 - část FSV UK. Autor děkuje dvěma anonymním recenzentům i redaktorům časopisu za cenné připomínky, které mu pomohly opravit chyby, zpřesnit argumenty a zlepšit srozumitelnost textu.

\section{Bibliografie}

\section{Archivní prameny}

Vilhelm Aubert Report [1947] to the Rockefeller Foundation on my studies in the United States, 1.1. Projects, 767 Norway, University of Oslo, Humanities, box 4, folder 40, Rockefeller Foundation Archives.

Letter from Peter A. Munch [1947] to Eric Rinde, Chicago, March 4th 1947, file „Eric Rinde“, Institute for Social Research Archives.

Jahoda, Marie 1948 ,Letter from Marie Jahoda to Haakon Lie 30. 7. 1948 ‘ Columbia University RBML, Paul Lazarsfeld Papers, box 22, Folder: Norwey 9, 1 page.

Joan Gordon interview with Paul Lazarsfeld December 1961: pp. 53-98 Interview 2; Columbia University RBML, Paul Lazarsfeld Papers, Columbia oral history (Joan Gordon).

Karikatura P. Lazarsfeld 18. 11. 1948 (Salo Grenning - Pedro) Columbia University RBML, Collection Paul Lazarsfeld Papers, box 22, Folder: Norwey 7, 1 page. 
Letter PFL to SSCR 1948 ,Letter from Paul Lazarsfeld to Dr. Pendelton Herring Director Social Science Research Council October 1948`Columbia University RBML, Collection Paul Lazarsfeld Papers, box 22, Folder: Norwey 8, 3 pages.

Letter PFL to Rinde 1949 ,Letter from Paul Lazarsfeld to Eric Rinde 27. 9. $1949^{`}$ Columbia University RBML, Collection Paul Lazarsfeld Papers, box 22, Folder: Norwey 2, 4 pages.

Letter PFL to Rector Otto Lous Mohr, October 10th 1949, in Coucheron-Jarl's Papers, Institute for Social Research Archives, Oslo, Norway.

Salo Grenning - Pedro https://en.wikipedia.org/wiki/Salo_Grenning.

Training Guide 1948 Training Guide on Constructing Questionnaires and Interview Schedules for Sociology 195-196. Oslo Edition, Oslo: Universitetets Studentkontor. Columbia University RBML, Paul Lazarsfeld Papers, box 22, Folder: Norwey 1.

Dagbladet 1 [1948] 27. 10. 1948, str. 1.

Verdens Gang 17. 11. 1948, Nr. 268, str. 1.

\section{Literatura}

Barton, Allen H. [1957]. Sociological and Psychological Problems of Economic Planning in Norway, PhD in sociology, Columbia University 1957 (University microfilms, Ann Arbor, Mich. L.C. Card no. Mic. 58-1331).

Barton, Allen H. [1982]. Paul Lazarsfeld and the Invention of the University Institute for Applied Social Research. In. Holzner, Burkart - Jiri Nehnevajsa (ed.). Organizing for Social Research. Cambridge, Mass.: Schenkman Publ., s. 17-82.

Barton, Allen H. [1998]. Occupational Class and Vote in the Norvegian Election. Research Note. Scandinavian Political Studies 21 (1): 72.

Birkelund, Gunn Elisabeth [2006]. The genesis of Norwegian sociology - a story of failures and success. Sosiologisk Årbok 3-4: 41-67.

Coleman, James [1982]. Introduction. In. The Varied Sociology of Paul F. Lazarsfeld. (Writings Collected and Edited by Patricia L. Kendall), s. 1-8

Fleck, Christian [2000]. Wie Neues nicht entsteht: die Gründung des Instituts für höhere Studien in Wien durch Ex-Österreicher und die Ford Foundation. Österreichische Zeitschrift für Geschichtswissenschaften 11 (1): 129-177.

Fleck, Christian [2017]. Warum Wien nicht zum mitteleuropäischen (Ausbildungs-) Zentrum der empirischen Sozialwissenschaften wurde. In. Reiter, Wolfgang L. - Mikoletzky, Juliane -Matis, Herbert - Ash, Mitchell G. (ed.). Wissenschaft, Technologie und industrielle Entwicklung in Zentraleuropa im Kalten Krieg. Wien.

Hogan, Michael J. [1987]. The Marshall Plan. America, Britain, and the Reconstruction of Western Europe, 1947-1952. Cambridge: Cambridge University Press.

Jeřábek, Hynek [2014]. Slavné sociologické výzkumy (1899-1949). Praha: Sociologické nakladatelství (SLON).

Jeřábek, Hynek [2019]. Od tréninkového centra k převládajícímu paradigmatu poválečné sociologické metodologie. Cesta kolumbijské školy od porážky k víťzství. Historická sociologie 2: 101-119.

Platt, Jennifer [1998]. A Brief History of the ISA: 1948-1997. Montréal: The International Sociological Association / ISA.

Sills, David [1987]. Paul F. Lazarsfeld 1901-1976. A Biographical Memoir by David Sills. In. Biographical Memoirs 56. Washington D.C.: The National Academy Press, s. 251-282.

Slaatta, Tore [2016]. Early Nordic Media Research and the Special Case of Norway. In. Simonson, Peter - Park, David W. (ed.). The International History of Communication Study. New York: Routledge, s. $174-191$.

Thue, Fredric W. [2006]. In quest of a Democratic Social Order. The Americanization of Norwegian Social Scholarship 1918-1970. Oslo: University of Oslo.

Hynek Jeřábek ( $\left.{ }^{*} 1949\right)$ je profesorem sociologie na Univerzitě Karlově. Zabývá se metodologií a historii empirického sociálního výzkumu a vyučuje na ISS FSV UK a na katedře sociologie FF ZČU v Plzni. Je autorem několika článků v Historické sociologii a také např. monografie 
Slavné sociologické výzkumy 1899-1949 (SLON 2014). Koncem roku 2019 vyšla jeho kníž$k a$ Úspěšné ženy ve stínu slavných mužů. Příběhy pěti žen, které ovlivnily podobu sociologického výzkumu (Karolinum 2019). Anglicky publikoval monografii Paul Lazarsfeld and the Origins of Communications Research (Routledge 2017 a 2019). 